\title{
UUM JOURNAL OF LEGAL STUDIES
}

http://e-journal.uum.edu.my/index.php/uumjls

How to cite this article:

Rafique, R. B., \& Venugopal, A. V. (2021). Preventive measures to mitigate the risk of fraud in letters of credit transactions in Malaysia. UUM Journal of Legal Studies, 12(1), 27-49. https://doi.org/10.32890/uumj1s2021.12.1.2

\section{PREVENTIVE MEASURES TO MITIGATE THE RISK OF FRAUD IN LETTERS OF CREDIT TRANSACTIONS IN MALAYSIA}

\section{${ }^{1}$ Rushmila Bintay Rafique \& A. Vijayalakshmi Venugopal}

Faculty of Business \& Law, Taylor’s University, Malaysia

${ }^{1}$ Corresponding author: rushmila93@hotmail.com

Received: 9/4/2020 Revised: 19/8/2020 Accepted: 5/9/2020 Published: 31/1/2020

\begin{abstract}
This article attempts to analyse the issue of fraud in Letters of Credit (LC) transactions, also known as documentary credits. There are numerous reported cases of fraud in LC transactions, which remain a continuing risk. The UCP 600 is a popular standard of practice for banks, which confirms that banks must honour payment to the seller upon full compliance with the documentary credit requirements. Such payments have been made despite being presented with falsified documents or substandard goods being delivered. It might not be realistic to expect that the International Chamber of Commerce (ICC) can create global standards relating documentary credits, which cover the practicalities of the existing system and relevant legalities applicable to the letter of credit system in international trading. Each party involved may have a responsibility to take some preventive measures to mitigate the risk of fraud. The doctrinal method is used to
\end{abstract}


conduct this study because it involves an in-depth analysis of the gap within the Malaysian system and the strategies that may be adopted to overcome the risks associated with LC fraud. Findings reveal that LC documents can be easily falsified, and the occurrence of LC fraud is not uncommon in Malaysia. However, given the lack of literature it has not been highlighted previously. The primary focus of this article is to suggest preventive measures that the respective parties could take to protect themselves from fraudulent dealings involving LCs.

Keywords: Letters of Credit (LC), fraud, UCP 600, Malaysia, preventive measures.

\section{INTRODUCTION}

In 2011, LC were used in about USD 2.3 trillion of global trade which amounted to 12.5 percent of international trade in terms of goods (Niepmann \& Schmidt-Eisenlohr, 2013). Furthermore, the average monetary value of The Society for Worldwide Interbank Financial Telecommunication (SWIFT) letters of credit in 2015 was USD 350,000 . There was a significant decline of 45 percent from the 2014 average monetary value of SWIFT letters of credit (USD 643,000). The ICC Global Trade and Finance Survey 2016 contended that this dropin value was due to various reasons: weak economic environment, fall in commodity prices, allegations of fraud as well as banks facing an upsurge of court injunctions barring payment under bank independent undertakings, etc. (ICC Global Trade \& Finance Survey, 2016). However, in 2016, the average value increased by 32 percent and reached an average value of USD 463,000 (ICC Rethinking Trade $\&$ Finance, 2017). LCs, also known as documentary credits, are very significant to global trade. The courts choose not to interfere with the LC operating mechanism, because, as Kerr J. stated in RD Harbottle (Mercantile) Limited v National Westminster Bank Limited[1978]1 QB 146, "It is only in exceptional cases that the courts will interfere with the machinery of irrevocable obligations assumed by banks. They are the lifeblood of international commerce." One of the objectives of LC being the most prevalent method of payment is because it protects the interest of both parties in a particular transaction. It ensures liquidity to both the importer and the exporter and allows a local entity to sue 
in the event of a dispute on payment. Letters of credit are preferred over other means of payment as they provide "security, liquidity, and proximity" (Laryea, 2002). These are fundamental requirements in global trade.

a) Security: An exporter (seller) who secures a letter of credit with complying documents can ship the merchandise, secure in the knowledge that the payment will be effected by the bank. It assures the exporter that the payment shall not be disrupted if any contractual dispute arises. Simultaneously, the importer (buyer) can pay the host bank and obtain the required paperwork to take delivery of the merchandise; with the knowledge that the precise merchandise has been shipped according to the underlying contract. The credit guards the importer against the risk of reimbursing an exporter who has not fulfilled his/her payment duties stipulated in the original contract. Also, the banks which undertake payment or deferred payment obligations, even before they are recompensed, obtain security over the shipping documents. The issuing banks acquire security over the buyer's general assets, presented documents and the goods represented in those complying documents.

b) Liquidity: Documentary credits provide liquidity for both buyer (applicant) and the seller (beneficiary), primarily for the period of shipment. For instance, the seller usually provides documents shortly after the goods have been shipped and obtains cash payment or accept draft which can be negotiated or discounted for cash.

c) Proximity for claims: In LC transactions, the buyers deal with the issuing bank and the sellers deal with the confirming bank. This provides each party with an entity to approach if something goes wrong with the payment in their own countries and can avoid expensive litigation abroad with a foreign and unfamiliar bank.

A breakdown of proposed bank intermediated trade finance transaction by type shows that commercial letters of credit (38\%) is the most common way of financing international trade followed by the other methods such as collection (17\%), open financing for accounts and supply chains (17\%), standby LCs (17\%), guarantees (8\%), and others $(3 \%)$. Provided that letters of credit are meant to facilitate trade, some 
specific attributes increase the risks associated with fraud while being used as a payment method in both domestic and global trade. Those attributes are that of the geographical distance between the parties, the usage of documentation, the vast diversity of the legal systems from a global perspective, as well as the restrictive proposition of the fraud exception rule. Such susceptibilities may diminish the worldwide popularity of LC as the most significant mode of payment in the global trade arena. It must be highlighted that the area of LC fraud is not a frequently mentioned issue when it comes to the usage of LC transactions. This article attempts to bridge the gap by suggesting practical methods to prevent the risk of fraud within LC transactions.

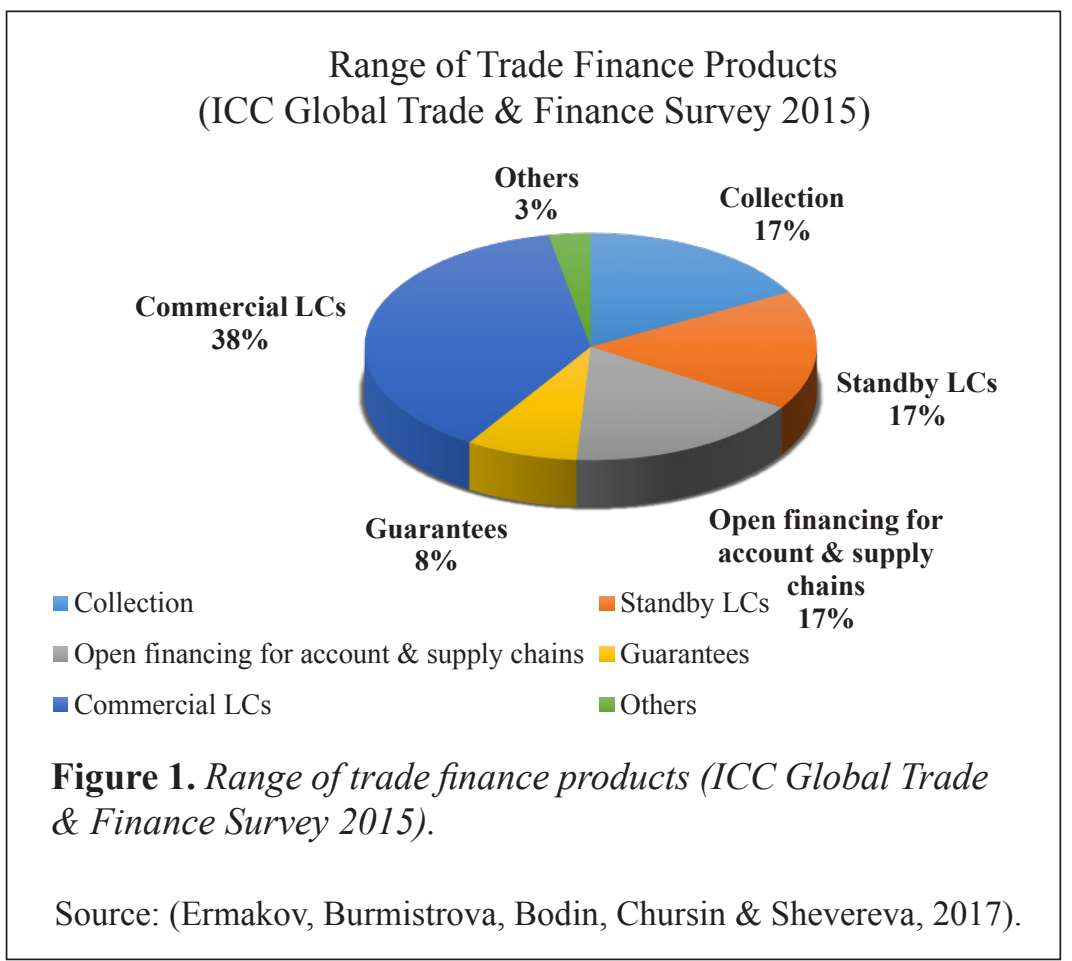

\section{Laws Governing Commercial Letters of Credit}

The International Chamber of Commerce (ICC) provides the main source of law which governs commercial documentary credits, the codification of relevant usage and customs under the Uniform 
Customs and Practice for Documentary Credits (UCP). In addition to the UCP, the ICC has similarly established other guidelines such as the eUCP, Uniform Rules for Demand Guarantees, International Standby Practices for Independent Guarantees \& Standby Documentary Credits (ISP98) and Uniform Rules of Contract Rules. The International Standard Banking Practice for the Examination of the Documents under Documentary Credits (ISBP) was introduced by the International Chamber of Commerce to explain the details as to how to apply the UCP 600 within the banking practices. The United Nations Commission on International Trade Law (UNCITRAL) took an initiative to introduce a standard legislation for Independent Guarantees and Standby Letter of Credit (Kozolchyk, 1979). Despite having these international frameworks to regulate the operation of LC, these have also been mentioned in some national jurisdictions, in civil law countries such as Greece, Honduras, and Mexico, etc (Alavi, 2016). In contrast, in common law jurisdictions, such as the United Kingdom, Malaysia and Bangladesh, legal issues of commercial LC are subjected to case laws (Alavi, 2016). The Uniform Commercial Code (UCC) is the legislative enactment in the United States that most closely reflects contemporary documentary credit practices.

In 2016, the most recent version of the UCP was introduced by the International Chamber of Commerce (ICC), acknowledged as the UCP 600. The ICC envisioned that the current version of the UCP would ensure consistency and certainty that is unaffected by different legal systems. The current version of the UCP has gained popularity over the years; many scholars considered it to be a forward movement in harmonising the usage of commercial documentary credits in global trade (Rodrigo, 2011). This was achieved by a number of ways such as reducing the number of provisions from 49 to 39; ensuring better clarification by construing terms such as "honour", "presentation" and "negotiation"; identification of agents and carriers and establishing new standards of examination of documents by the banks. As per Article 1 of the UCP 600, "it has no legal effect unless incorporated into a contract by the parties". After the incorporation of UCP 600 , specific provisions can be completely or partially excluded by legislation or express contractual terms (Chhina, 2013). Several issues are overlooked and not included within the UCP 600 guidelines (such as fraud); which means in order to fill the gap in the law in 
general, the case law principles are taken into consideration by the judges (Rodrigo, 2011).

\section{Fundamental Principles of Commercial Letters of Credit}

There are two principles which regulate the operation of LC, namely, the strict compliance and the principle of autonomy. Following the principle of strict compliance, the issuing bank and the confirming bank are only entitled to reimburse - where the documents strictly comply with the terms of the credit. Winslow J. explained the principle in the Malaysian case of Overseas Union Bank Limited. v Chua Teng Hwee [1964] 30 MLJ 165 "where the documents are not in compliance, the issuing bank has the authority to refuse payment, and having paid, they can demand a refund" (Ellinger, 1970). Previously, the principle was rigid and there was no room for discrepancies which resulted in a $70 \%$ rejection due to non-compliance (Wood, 2008). With reference to the term "strict compliance", a crucial question arises, that is, to what extent should the documents strictly comply with the terms of the credit. As stated by Article 2 of the UCP 600, "a complying presentation means a presentation that is in accordance with the terms and conditions of the credit, the applicable provisions of these rules and the international standard banking practice". Later, the UCP 600 laid down guidelines to be followed by the respective banks to inspect the documents. For instance, Article 14 states the responsibilities of the bank which need to be fulfilled following the standard for examination of documents. The UCP 600 has presented three new features: "examination of the documents on their face" (Article 14a), "the time specified to the banks for examination" (Article 14b), and "consistency between tendered documents" (Articles 14d and e).

The principle of autonomy dictates that the issuing bank cannot refuse payment on the basis that the bank did not receive the applicant's funds or that they have some kind of 'rights of setoff' against the buyer (Hare, 2004). Letters of credit establish payment obligations that are completely separate from the underlying contract as specified in Article 4 of the UCP 600. As specified by Lord Diplock in the landmark case of United City Merchants (Investments) Limited $v$ Royal Bank of Canada, The American Accord [1983] AC 168 "the autonomy rule upholds the commercial significance of the guarantee that authorise the credits to impose an absolute obligation to pay 
and reassures that the parties are dealing with documents instead of goods". The first case to uphold the autonomous nature of LCs in Malaysia was the case of Ka Wah Bank Limited v Hong Leong Bank Bhd \& Ors. (Originating Summons No. C3-31-369 of 1986). This was the only case in Malaysia dealing with the principle of autonomy as a pivotal issue. However, there are exceptions to this principle. The first possible exception is the fraud exception, whereby the bank may refuse to pay if it comes across any 'compelling evidence' of the seller's fraudulent presentation. Lastly, in some situations where there is illegality, the court has the discretion to apply fraudulent misrepresentation, mistake or frustration.

\section{Fraud in Letters of Credit Transactions}

Fraud happens to be one of the most popular and oldest catastrophes within the commercial trade practice. "As long as there have been commercial systems in place, there have been those who have tried to manipulate these systems" (ICC International Maritime Bureau, 2002). According to Spencer Pickett (2006), fraud imposes huge costs on both small and large enterprises. It should take centre stage to generate more awareness. The risk of potential fraud will increase if the parties involved are unaware of the threats, and the "anti-fraud preventive" measures which can help them reduce the likelihood of being a victim of fraud are not in place. Defrauders can target companies that do not have any effective regulatory measures to protect their interest. They guard themselves by finding legal loopholes in different jurisdictions in order to conceal their misconduct from the law enforcement bodies (ICC Commercial Crime Services, 2002).

Mukundan (2008) emphasised that fraud schemes are typically becoming more sophisticated and advanced day by day (Alavi, 2016). As the banks act as guarantors, they only pay attention to the examination of the required documents. As a result, the parties who are involved in the LC transactions can use the documents to commit fraud against the banks. In 1995, it was reported that losses due to LC fraud reached $\$ 0.5$ billion [Note: here begins the usage of the " $\$$ " sign to denote American dollar denomination. Refer to paragraph 1 under INTRODUCTION] in the US (Barnes and Byrne, 1996). As per the Commercial Crime Bureau, in 1998, the loss due to LC fraud was 2.4 billion Hong Kong dollars (about US $\$ 0.3$ billion) with 21 court cases 
related to LC fraud (Yanan, 2011). A Bank of Tokyo report stated that the Malaysian Police arrested an agent associated with fraud amounting to RM100 million which involved using false LCs (Veera, 2010). There were numerous fraud cases internationally in recent years, and the amount involved has risen as well, such as that in The Nande Group and Mou Qizhong Case in 2000, where Mou Qizhong's LC fraud resulted in the bank losing $\$ 40$ million. Even with a fraud exception, the high standard of proof required makes it challenging to prove that there was fraud - there must be "compelling but not irrefutable evidence of fraud" (Goode, 2010, p. 1102). Therefore, it is insufficient to show that a reasonable banker thinks there was fraud involved, as was stated in the case of Society of Lloyd's $v$ Canadian Imperial Bank of Canada [1993] 2 Lloyd's Rep. 579. Additionally, Sealey \& Hooley pointed out that, "it remains a cause of some unease that the seller, however innocent himself, becomes entitled to payment through tender of a document that carries a deliberately false shipping date, when tender of a document giving the true shipping date could have been rejected as discrepant" (Goode, 2010, pp.1104-07).

The Director of International Commercial Crime Fraud observed that the buyer, seller or any financial intermediary could commit fraud in LC transactions (Hashim \& Mahdzan, 2014). According to Hamed Alavi (2016), there are several possible scenarios when it comes to LC fraud. The fraudsters use false or forged documentation to offer merchandise which is of high market value at a very low price. Generally, the seller (beneficiary) is the one committing fraud. Nevertheless, it could alternatively be the buyer, or both. Fraudsters have created many innovative methods to deceive the banks and the relevant parties involved in LC transactions.

Consequently, two observations should be highlighted. First of all, there is no internationally recognised legal regime for mitigating the risks associated with LC fraud. Fraudsters protect themselves from law enforcement bodies by identifying the gaps within the particular jurisdiction (ICC Commercial Crime Services, 2002). The companies participating actively in global trade are suggested to take into account the risks associated with fraud and establish effective "anti-fraud measures" to decrease the prospect of becoming a victim to fraud. Secondly, scholars such as R.P. Buckley, X. Gao, R. Goode and E. McKendrick suggest that the prevention of fraud within LC transactions has not been discussed extensively. 


\section{METHODOLOGY}

This study is conducted following the doctrinal research approach. It is mainly library and internet-based; conducted based on a qualitative doctrinal legal research method (Yaqin, 2007, p 10). This method is suggested to be the most suitable approach because the doctrinal method is a problem structure including numerous stages which include, contextual reading, locating primary materials, identifying the current legal issues, gathering relevant facts, scrutinising the gap within the law, and analysing all of the subject matter within the context. The fundamental objective is to gain new knowledge and analyse the concepts to recommend reform or change (Hutchinson \& Duncan, 2012, p. 83). This method is selected for this article because it involves identifying the pertinent gap within the system along with an in-depth analysis of the problem with regard to Malaysia and finally looks into strategies to prevent the risks associated with letters of credit fraud.

\section{DISCUSSION}

\section{Malaysian Approach to Fraud in Letters of Credit}

There is no specific statutory provision in Malaysia dealing with fraud in LC transactions. The Malaysian Contracts Act 1950 (Act 136) governs all kinds of contractual disputes. Another significant source would be the Malaysian Penal Code (Act 574). Fraud associated with LC transaction is subject to the form of punishment specified under the Malaysian Penal Code. Normally, fraudsters in documentary credit fraud cases are charged under section 420 and/or section 463, read together with sections $464,467,468,471$, and 474 as they cover the subject of fraud regarding "valuable security" and documentary credits are considered as such (R. Che Hashim, 2010).

In the case of PP $v$ Ibrahim bin Salleh (Session Court, Kuala Lumpur 62-232-2006 and 62-162-2007), Ibrahim (the accused), who was a manager of a company named Jalinkom Company was instructed to deliver timber to a Thai company named Leowood Company as stipulated under the sales contract. The payment was to be made via letter of credit transaction. Following the terms of the credit, Ibrahim (the said manager) was required to present certain documents in order 
to be compensated by the bank; the documents being the bill of lading, commercial invoice, and the packaging list. The bank relying on the tendered documents and honouring the credit, accordingly, paid him USD $\$ 1,215,250$. Later, it was discovered that the goods (timber) were never delivered as stipulated under the sales contract, and that the bill of lading was also forged. The prosecution was successful in proving that the bill of lading was duplicated, and the contents were modified by the manager. Subsequently, he was charged under section 420 of the Penal Code for having defrauded the Bangkok Bank Public Company Limited via Maybank Berhad. Thus, it can be seen that as the banks are only concerned with documentary compliance; it arises that when documents are presented, it is impractical for the bank concerned to examine or inspect the authenticity of all the documents presented, which ultimately allows the fraudsters to utilise this pattern to perpetrate fraud.

On another occasion, following a report by the Bank of Tokyo, the Malaysian police enforcement unit arrested an agent who was associated with LC fraud involving RM100 million by means of fake LCs (Veera, 2010). The police enforcement unit discovered that the agent was involved with a gang of fraudsters. The gang was involved in defrauding other local banks as well using false LCs and they were not in contact with one another so as to avoid exposure. Based on the current events and cases, it is safe to suggest that the existence of letters of credit fraud in Malaysia is not insignificant (Che Hashim, 2011).

Furthermore, in Malaysia, fraud is the only recognised exception to the autonomy principle of commercial letters of credit. Following the English courts, in the case of LEC Contractors Sdn Bhd v Castle Inn Sdn Bhd [2000] 3 MLJ 339, it was held by the Malaysian Court of Appeal that the "authorities we have referred to clearly indicate that in order to justify any injunction to stop payment, there must be clear evidence of fraud on the part of the first defendant which comes to the knowledge of the second defendant. Bad faith or unconscionable conduct by itself is not fraud". On the other hand, in the case of Pasukhas Construction Sdn Bhd v MTM Millennium Holdings Sdn Bhd [2016] 1 CIDB-CLR 269, Hishamodin J., notwithstanding the acknowledgment of the principle laid down in LEC Contractors which viewed fraud as the only exception to the principle of autonomy, showed his regret for being bound to follow the decision under the principle of binding precedent. 


\section{The Experience of Malaysian Banks in Dealing with Fraud in Letters of Credit Transactions}

As discussed earlier, there is always an adverse effect on the buyer when fraud is committed by the seller via LC dealings, mainly because the buyer is still under an obligation to repay the bank for credit facilities, albeit he has received defective or no merchandise at all. The Malaysian court cases suggest that cases involving letters of credit fraud follow a similar modus operandi. Nevertheless, it is observed that there is very limited academic research in this specific area of LC fraud with regards to the Malaysian perspective.

To explore the severity of LC fraud in Malaysia, given the lack of literature, Che Hashim and Mahdzan (2014) conducted a study with several objectives in mind such as: analysing the severity of fraud in LC based on local bankers' experiences, examining the common modus operandi utilised by the fraudsters, and underlining the methods employed by the Malaysian commercial banks dealing with LC fraud. In this study, LC experts and bank officers shared their perception of how recurrently they came across cases of fraudulent LC in their organisations. One banker commented:
"In terms of percentage, we rarely come across fraud cases. The occurrence of $L C$ fraud is very, very low. I can confidently tell you that in banking, the highest fraud cases will be in regards to credit card and the lowest involve LC."

Therefore, following the above-mentioned statement, it appears that the manifestation of fraud within letter of credit transactions is usually insignificant and relatively rare (Hashim \& Mahdzan, p 4). On the other hand, an expert on LCs, in the same study remarked (Hashim \& Mahdzan, pp 5-6):

"It is difficult to be specific; I probably can't estimate. But I don't see any reason why the situation in Malaysia should be any different from any other parts of the world because fraudsters exist in every country. All commercial centres will have about the same proportion of crooks that you would have anywhere else. So, in Dubai, London, and Hong Kong, there will be larger numbers because 
the volume is higher, but the proportion is exactly the same. In Malaysia too, there has been some major fraud in the past."

Thus, it can be ascertained that the observations provided by both the banker and the LC expert contradict each other. Professor Hashim and Professor Mahdzan took one more step to explore the validity of these conflicting statements by analysing the respondents' comments (the banker and LC expert). Their study concluded that "documentary fraud" was the most prevalent form of LC fraud (Hashim \& Mahdzan, p 5). The study also distinguished between three types of letters of credit fraud in Malaysia: "documentary fraud", "container fraud", and "insurance fraud" (Hashim \& Mahdzan, pp. 5-6). Over-insurance on goods is the most basic form of cargo insurance fraud (Conway, 1990). The seller insures the products at a price greater than its real value. Then the seller himself strategises for occurrence of loss or harm, and in this way, the seller benefits from the insurance by demanding a premium greater than the real value of the product. The other form of LC fraud is called container fraud, that is, when the seller ships fraudulent goods to the buyer.

As cited earlier, the common modus operandi used by the fraudsters involved several kinds of scams. As stated by the bankers and LC experts from their own experiences, it mostly includes presentation of false/ forged documentation (invoices, delivery orders, and bills of lading) along with fraud perpetrated by the applicant or the beneficiary, and fraud committed by a third party such as a shipping agent. Statistical research indicates that 45 percent of the bankers have observed that the falsification of bills of lading is the most common modus operandi utilised by the fraudsters to commit LC fraud (Hashim \& Mahdzan, $\mathrm{p}$ 6). As observed in cases such as PP v Ibrahim bin Salleh, fraudsters, using forged bills of lading or fabricated authenticity of a non-existent cargo, delude the bank into thinking that the cargo exists when it does not.

The final stage of the article explores detection of fraud and the actions taken by the banks once fraud is discovered. Once fraud has been detected, an investigation is conducted at the outset before any further actions are carried out. As soon as fraud is distinguished, the respective credit officer handling the alleged client is cautioned to carry out more detailed inquiries. All transactions that involve that 
particular client are immediately frozen, and subsequently a full investigation is carried out and comprehensive advice is provided by the credit officer. However, it ought to be emphasised that the bank must have concrete evidence that actual fraud has been committed before the cancellation of the client's credit facilities. Otherwise, the bank may be exposed to the risk of being sued by the client for wrongfully ceasing the line of credit (Hashim \& Mahdzan, p. 6).

\section{Recommendations of Preventive Measures}

The next part of the article suggests particular preventive measures that each party can adopt as anti-fraud strategies to combat the risks associated with LC fraud.

\section{Modernising Letters of Credit Transactions}

FinTech or Financial Technologies is the practice of introducing the advancements in technology into financial and banking institutions (Amer, Barberis \& Buckley, 2016). Ever since the 2008 financial catastrophe, banks have been interested in modernisation of trade finance between international exporters and importers (Hennah \& Jarold, 2017). The usage of paperless documents could save up to USD \$50 million each year (Tennenbaum, 2016). The main idea is to strive for a proper balance between effectiveness and maintaining the commercial feasibility when it comes to LC transactions. Significant FinTech mainly include blockchain and smart contracts.

Blockchain is a subset of distributed ledger technology. Briefly, it refers to a chronological and comprehensive database of transactions (Reyes, 2016). The transactions are categorised into separate "blocks" which are time-stamped and linked to the previous blocks (Piazza, 2017). Decentralisation is one of its main characteristics, meaning neither an entity nor an individual can control the blockchains. Instead, each computer or "node" is connected to the same peer-topeer network that runs under the same protocols (Dewey \& Emerson, 2017). Blockchains are also used to store documents and verify them through a 'consensus' mechanism (Wright \& Filippi, 2015). This is the main reason why blockchains are helpful for parties concerned about document compliance and management. Currently, blockchains have also been used to generate documents such as bills of lading in LC transactions (Southurst, 2016). International trade involves 
numerous documents and blockchain can be an effective way to store, verify and organise documents.

In 1996, the term "smart contract" was first introduced by Nick Szabo and can be described as a set of written mathematical rules which, once generated, automates certain promises between parties (Reyes, 2017). Vending machines can be a simple example to explain how smart contracts work: after a person chooses an item and inserts the appropriate sum of money, the machine automatically dispenses the corresponding item. This suggests that smart contracts can successfully execute agreements between parties in a fast and secure manner without a need for a middleman or an invoice (Hughes, 2018). Consequently, it can be observed that both blockchains and smart contracts provide an opportunity to act as a power-duo to automate portions of LC transactions, such as payment (McJohn \& McJohn, 2016).

In 2019, the Hongkong and Shanghai Banking Corporation Limited (HSBC) pioneered Malaysia's first pilot blockchain LC transaction (Fintech Malaysia, 2019). The transaction involved a Malaysian company named Simply Packaging Sdn. Bhd. importing resin from a Singaporean company. HSBC Malaysia acted as the issuing bank and HSBC Singapore was the advising or nominated bank (HSBS News Release, 2019). Stuart Milne, Chief Executive Officer of HSBC Malaysia stated, "I am very pleased that HSBC has pioneered Malaysia's first pilot blockchain LC transaction. This showcases our strong commitment and ability to support cross-border trade by Malaysian businesses using cutting-edge technology platforms" (New Straits Times, 2019). Thus, this could be a stepping-stone for all the banks in Malaysia. It will help banks expedite transactions and ensure transparency, which would ultimately mitigate the risks associated with LC fraud.

\section{Preventive Measures to be Adopted by the Issuing Bank and Confirming Bank}

Under Article 5 of the UCP 600, to honour a credit, banks are only concerned with documentary compliances and not the goods or services. As a result, following Article 5 and Article 14(a) of the UCP 600 which deal with the standards for examining documents: 
"A nominated bank acting on its nomination, a confirming bank if any and the issuing bank must examine the presentation to determine, on the basis of documents alone, whether or not the documents appear to constitute a complying presentation". The foremost goal of the UCP 600 guidelines is to separate the terms of the LC from its original sales contract and by setting a limiting factor with the banks to solely deal with documentary requirements, thereby facilitating the course of global trade and fulfilling the growing demand for crossborder transactions. However, there are severe consequences such as: it makes the LC operating mechanism vulnerable to fraudulent misconduct. Overall, placing such limitation on the bank to solely rely on the presented documents has caused many scholars to criticise the UCP 600. Shoia Lin Kuore remarks on the necessity to extend the bank's duty to check the performance of a seller in satisfying his obligations stipulated in the sales contract, instead of solely relying on documents to prevent the risk of fraud in letters of credit transactions (Demir-Araz, 2002). Nonetheless, this is looking from an international perspective. There must be some preventive measures that can be adopted by local banks to combat the risk of fraud.

One way to mitigate the risk of fraud would be to offer "superservice", which is basically a service that involves fulfilling the responsibilities of examining the accuracy, authenticity, and legitimacy of the documents provided by the seller before undertaking payment. As suggested by Yanan (2012), it must be compulsory for the banks to check the authenticity of the documents presented before reimbursing the beneficiary. The United Nations Conference on Trade and Development was the first to recommend such services to the banks to prevent the risk of fraud (UNCTAD Report, 1983). Nevertheless, it invited some criticism as well, given the fact that it would be unworkable for the banks to check the authenticity of the vast number of shipping documents presented for each transaction. Realistically, the banks can confirm the existence of the vessel as well as the seller, but it is quite unworkable for the bank to check whether the goods were loaded in the vessel and to ensure the quality and nature of the goods as per the buyer's instructions (UNCTAD Report, 1983). Moreover, an increase in document inspection services would increase the cost in terms of money and time. Consequently, it is further suggested that such a "super service" should be optional, with an additional fee stipulated by the banks (UNCTAD Report, 
1983). It depends on whether the banks can provide such a service, given that they have the necessary resources to be able to perform such inspections. Additionally, it also depends on the demands of the applicant: If the buyer is satisfied by the credibility of the seller, such services may not be required.

Buyers from developing countries are more interested in using such services (Bank of China, 2008). Following the report of such services, the client can get acquainted with the overseas trade partner's background, solvency capability, credit status, etc. Using this service, the bank enables its client to confirm the legitimacy of bills of lading and track the process of delivery, thereby preventing the risk of LC fraud to a great extent. It seems ideal for the banks in Malaysia to adopt such services to combat the risk of fraud with LC transactions. Banks are not obligated to provide such services: It only depends on the market needs and the resources available to the banks. Moreover, offering such services allow the banks to hold a safer position, as they are willing to offer measures that would ensure certainty and the clients can choose whether to take advantage of it or not.

Generally, LC fraud affects the banks in two ways. The first situation is where the bank's interest is at stake; detrimental loss suffered by the defrauded buyer who might go insolvent eventually, and thus becoming unable to recompense the bank. The second scenario is when the buyer and the seller together are involved in defrauding the bank (Todd, 1996). For both cases, the bank needs to further investigate the financial standing of the parties involved. In addition, they need to investigate the client's nature of the transaction which may reveal clues concerning fraud or discover discrepancies in documents submitted by the seller. Nevertheless, such further inquiries are timeconsuming and require skilled experts, and therefore, additional costs are involved, and it is less profitable for the bank when dealing with the particular transaction.

As a result, it can be suggested that banks need to be prudent and they must have sufficient fraud detection training programmes for their employees to be aware of the risks associated with LC fraud (Liu, 2006, p. 21). Having knowledge of the creditworthiness of their LC applicants is another way to raise awareness of scams that might not be detected from the face of the documents. Furthermore, 
an inspection of documents presented by new clients (inspection of the bills of lading and commercial invoices) is highly recommended (Mukundan, 2008).

\section{The Buyer (Applicant)}

One of the most common scenarios of LC fraud is where the parties enter into a contract and according to the contract, LC is stipulated to be the mode of payment. Following the terms of the credit, tendered documents are presented by the seller to the issuing bank. However, in reality, no goods were shipped by the seller. Following the UCP guidelines, the bank processes the payment as the documents were consistent with the LC terms. The buyer receives no goods or goods of questionable quality and by then, the seller has fled. Hence, it is crucial to explore the precautionary measures that can be adopted by the buyer to mitigate such risks of fraud.

As mentioned previously, it is highly recommended to check the financial standing of the seller before entering into any type of contract. The buyers must keep in mind that bearing the cost of gathering relevant information on his/her trade partner's financial standing can be more affordable than the future loss from being defrauded by a fraudulent seller. Therefore, preliminary investigations may help the buyer to choose a trustworthy seller, as well as ensuring a smooth flow of international trade transactions.

Following the principle of autonomy under Articles 4 and 5 of the UCP 600 , the banks will honour the credit, simply based on documentary compliances. The operation takes place by presenting the required documentation to the issuing bank, even though the seller may not have fulfilled his obligations as stipulated under the contract. To diminish the risk of payment relying on false documentation or documents which inaccurately verify the performance of the beneficiaries' obligations specified in the sales contract, the buyers are recommended to hire an independent inspector and specify a condition in the agreement which clearly states that an independent third-party inspection certificate is required before the issuing bank honours the credit (Nelson, 2000, p. 48). These independent inspectors can offer various types of services such as the issuance of inspection certificates, verification of the quality and quantity of the goods, confirmation of loading of the goods, authentication of packaging, etc. 
Another way to mitigate LC fraud would be to insert clauses specifying the date of shipment and the name of the contracted vehicle in the original sales contract (Xiaorong \& Ruiping, 2005). This way, the buyer will be able to use databases such as the Lloyd's List Intelligence to confirm "the location of the ship, its availability, its capacity and the possible date of arrival at the port of destination" (Xiaorong \& Ruiping, 2005). Furthermore, the buyer may attach a "sale on approval" clause in the sales contract which means that the seller will only be paid once the buyer has approved the conformity of the delivered goods with the terms of the contract as recommended by the case of Sirius International Insurance Corp. v FAI General Insurance Co. Limited [2004] UKHL 54. It was held that the autonomy principle would not cover the condition in which the seller had expressly agreed in the sales contract that he could not draw down the amount in the letter of credit without the buyer's agreement. Therefore, it can be suggested that this can be another way for Malaysian buyers to protect their interests against fraud by inserting a "sale on approval clause" in the original contract. Such a clause should be very clearly specified in the contract and the arrangement must be contemplated during negotiations. If there is any ambiguity on whether such a clause was included, the courts might presume that there was no clear intention on the part of the buyer.

So far, many recommendations have been suggested to prevent the risk of fraud from escalating. Currently, many states are using the pre-shipment inspection services to inspect goods before the goods are shipped. For example, from the year 1999, Bangladesh made the pre-shipment inspection compulsory under the official Preshipment Inspection (PSI) Rules. Following the general rules and regulations, all kind of goods heading towards Bangladesh are inspected by designated inspection companies before shipping. The buyers need to pay a charge of percent of the assessable price of the shipment to the government through which the inspection fees are covered (Islam, 2008). One of the prerequisites to honour the credit is to present a satisfactory preshipment inspection report of the goods. The pre-shipment inspectors are under a contractual liability with the government to issue genuine reports. Inconsistencies can result in penalisation under the PSI Audit Agency Appointment Order. Thus, the buyer's interest is safeguarded as the goods are being inspected at the port of loading (Islam, 2008, p 10). It can be suggested that Malaysian buyers can also apply such 
measures to protect themselves from fraud by way of independent inspectors who can verify the quality and quantity of goods. Even if appointing pre-shipment inspectors can increase the costs of trade, it can ensure sufficient protection against credit fraud (Ho, 1997).

\section{The Seller (Beneficiary)}

As the seller, the main preventive measure that can be adopted in order to mitigate the risk of fraud would be the credit investigation of their respective trading partner. The inquiry ought to be done before both parties confirm that documentary credit should be used as the payment method for the particular transaction. Such investigations may include gathering information regarding the buyer's financial standing and trade history to ensure that the buyer and/or his agents are reliable. The seller may access such information from reputable local banks and specialised institutions that provide information on business credibility (Cheng \& Xiao, 2008).

Another effective way to prevent the risk of LC fraud in order to protect the seller's interest would be to audit the documents strictly. The international sales contract is the main foundation of the LC operating mechanism. As a result, it is suggested that the seller should take enough time to draft the contract with clear precision and emphasise the relevant documents (Tao, 2009). These relevant documents include the bill of lading, commercial invoice, insurance policy, certificate of origin, inspection certificate, and any other essential documents. This involves carefully checking the contract to ensure that there are no loopholes relating to fraud that the beneficiary can take advantage of. Lastly, the seller should have effective internal communication and a co-operative business relationship with the advising bank to verify "the credibility of issuing bank, avoid soft clauses in LC and be aware of the existing risks" (Ying \& Zhiyong, 2003, p 44).

\section{CONCLUSION}

As stated by Miroslav Volf, "in a way, fraud in business is no different from infidelity in marriage or plagiarism in scholarly work. Even people committed to high moral standards succumb" (Banerjee, 2015). Fraud appears to be a major issue and gives the impression of 
"a battle with many fronts"; each country relentlessly tackling it in its own capacity using their own methods.

This article attempts to portray the method in which LCs operate and the extent to which it depends on trust and confidence which gives opportunity to the defrauders and breeds complications that are challenging to remedy. Amendments to the UCP 600 suggested by this article is to remedy the issue of LC fraud.

It is also worth mentioning that it would be quite impractical for the ICC to create a set of global standards regarding LCs, which encompasses both the regulatory guidelines and the legalities relevant to the LC system in an international transaction. The banks and the international organisations also need to actively participate in the advancement of a uniform law, in relation to the practical issues arising from the LC system. The recommendations suggested by this article include modernisation of the LC transaction process by introducing blockchain technology; the banks can opt for services such as "superservice" in order to inspect the authenticity of the LC documents. The buyers and the sellers are highly encouraged to check the financial standing of their respective trading partners. They are also required to audit the documents carefully to ensure that the contract has no ambiguities relating to fraud.

The identified loopholes and the preventive measures suggested within this study is significant to the individual parties (the buyer and the seller) as well as the banking community. The precautionary measures recommended in this article need to be implemented by the parties involved in order to mitigate the risk of documentary credit fraud. In addition, this article provides different methods of combating the risk of LC fraud, taking into consideration both the international and domestic views in order to minimise the occurrence of fraud. Finally, it can be concluded that this research is to encourage practitioners, bankers and the parties involved to develop preventive and practical measures in both the commercial and legal fields.

\section{ACKNOWLEDGMENT}

This research received no specific grant from any funding agency in the public, commercial, or not-for-profit sectors. 


\section{REFERENCES}

Alavi, H. (2016). Mitigating the risk of fraud in documentary letters of credit. Baltic Journal of European Studies, 6(1), 139-156. https://doi:10.1515/bjes-2016-0006

Banerjee, R. (2015). Who cheats and how? SAGE Publications.

Che Hasyim, R. (2016). The UCP 600 rules in letter of credit (LC): Selected issues. UUM Journal of Legal Studies, 7,107-118. http:/www.uumjls.uum.edu.my/images/2016/107-118.pdf

Che Hashim, R., \& Mahdzan, N. (2014). Fraud in letter of credit transactions: The experience of Malaysian bankers. International Journal of Law, Crime and Justice, 42(3), 224236. https://doi.10.1016/j.ijlcj.2014.01.008

Chhina, R. (2013). Standby letters of credit in international trade. Alphen aan den Rijn: Wolters Kluwer Law \& Business.

Douglas, W., Arner, J. B., \& Ross P. B. (2016). The evolution of FinTech: A new post-crisis paradigm? Geo. J. Int'l L. 1271(47), 1272.

Ellinger, E. P. (1970). Documentary letters of credit: A comparative study. University of Singapore Press, 89-90.

Ermakov, V., Burmistrova, E., Bodin, N., Chursin, A., \& Sheverva, E. (2017). Range of trade finance products. ICC Global Trade and Finance Survey 2015.

Fiammetta, S. P. (2017). Bitcoin and the blockchain as possible corporate governance tools: Strengths and weaknesses. Penn. St. J.L. \& Intl' Aff.262(5), 275.

Fintech Malaysia. (2019). HSBC successfully pilots Malaysia's first letter of credit transaction on the blockchain-Fintech News Malaysia.https://fintechnews.my/21774/blockchain/hsbc-pilotsblockchain-letter-of-credit-transaction between-malaysia-andsingapore/

Hare, C. (2004). Not so black and white: The limits of the autonomy principle. CLJ, 288.

HSBS News Release. (2019). https://www.about.hsbc.com.my/-/ media/malaysia/en/news-and-media/191014-release-hsbcleads-malaysias-first-pilot-blockchain-lc-transaction.pdf

Hughes, B. (2018). Smart contracts: Here are the practical applications of this exciting block chain technology. https:// www.stamfordadvocate.com/news/article/Smart-ContractsHere-Are-the-Practical-13253496.php

Hutchinson, T. (2018). Researching \& writing in law ( $4^{\text {th }}$ ed.). Sydney: Thomson Reuters (Professional) Australia Pty Limited. 
Hutchinson, T., \& Duncan, N. (2012). Defining and describing what we do: Doctrinal legal research. Deakin Law Review, 17(1), 83. https://doi.10.21153/dlr2012vol17no1 art70

ICC Global Survey on Trade Finance 2016 - ICC - International Chamber of Commerce. (2017). https://iccwbo.org/publication/ icc-global-survey-trade-finance-2016/

Josias, N. D., \& Michael, D. E. (2017). Beyond bitcoin: How distributed ledger technology has evolved to overcome impediments under the uniform commercial code. UCC L.J., 47. 105, 107-08.

Ka Wah Bank Limited v. Hong Leong Bank Bhd \& Ors. (Originating Summons No. C3-31-369 of 1986).

Kozolchyk, B. (1979). The commercialisation of civil law and the civilisation of Commercial Law. La. L. Rev.

Laryea, E. T. (2002). Paperless trade: Opportunities, challenges and solutions (1 ed.). Kluwer Law International.

LEC Contractors Sdn Bhd v. Castle Inn Sdn Bhd [2000] 3 MLJ 339.

McJohn, S., \& McJohn, I. (2016). The commercial law of bitcoin and blockchain transactions. Uniform Commercial Code Law Journal, Forthcoming Suffolk University Law School Research Paper No. 16-13. https://ssrn.com/abstract=2874463

Mukundan, P. (2008). 'Fraud with L/Cs - latest modi operandi,' Speech of the Executive Director of the ICC commercial crime services and material at the 2nd Annual International Conference on Letters of Credit organized by ICC Austria, Vienna, 29 May 2008.

Niepmann, F., \& Schmidt-Eisenlohr, T. (2013). No guarantees, no trade: How banks affect export patterns. SSRN Electronic Journal. https://doi.10.2139/ssrn.2377407

Overseas Union Bank Limited v. Chua Teng Hwee [1964] 30 MLJ 165.

Pasukhas Construction Sdn Bhd v. MTM Millennium Holdings Sdn Bhd [2016] 1 CIDB-CLR 269.

Pickett, K. (2006). Enterprise risk management. Hoboken, N. J.: John Wiley \& Sons.

PP v Ibrahim bin Salleh (Session Court, Kuala Lumpur 62-232-2006 and 62-162-2007) Reyes, C. (2017). Conceptualising cryptolaw. SSRN Electronic Journal. https://doi:10.2139/ssrn.2914103

Reyes, C. (2016). Moving beyond bitcoin to an endogenous theory of decentralised ledger technology regulation: An initial proposal. 
Villanova Law Review, 61(1). http://digitalcommons.law. villanova.edu/vlr/vol61/iss $1 / 5$ ? utm_source=digitalcommons. law.villanova.edu\%2Fvlr\%2Fvol61\%2Fiss 1\%2F5\&utm medium $=$ PDF\&utm_campaign $=$ PDFCoverPages

RD Harbottle (Mercantile) Limited v. National Westminster Bank Limited [1978] 1 QB 146.

Rodrigo, T. (2011). UCP 500 to 600: A forward movement. Murdoch University Law Review, 18(2), 1-21. https:/elaw.murdoch.edu. au/index.php/elawmurdoch/article/view/85

Sirius International Insurance Corp. v. FAI General Insurance Co. Limited [2004] UKHL 54.

Society of Lloyd's v. Canadian Imperial Bank of Canada [1993] 2 Lloyd's Rep. 579.

Southurst, J. (2016). How blockchain contracts and IoT could save global shipping billions|news bitcoin news. https://news. bitcoin.com/blockchain-save-global-shipping-billions/

United City Merchants (Investments) Limited v. Royal Bank of Canada, The American Accord [1983] AC 168.

Veera, R. V. (2010). Broker picked up RM100 millions swindled using fake letter of credit, (n.d). The Star online.Extracted from the material supplied in the Workshop on Letter of Credit, An In-depth Understanding by Mr. Billy Fong, Crown Princess Hotel, Petaling Jaya, 9-10 April 2010.

Wood, J. S. (2008). Drafting Letters of Credit: Basic issues under Article 5 of the Uniform Commercial Code, UCP 600, and ISP 98. Banking Law Journal, 125(2), 103-149.

Wright, A., \& De Filippi, P. (2015). Decentralised blockchain technology and the rise of Lex cryptographia. SSRN Electronic Journal, 7. https://doi.10.2139/ssrn.2580664

Yaqin, A. (2007). Legal research and writing methods. LexisNexis Butterworths Wadhwa Nagpur.

Zhang, Y. (2011). Approaches to resolving the international documentary letters of credit Fraud Issue (Unpublished doctoral dissertation.). University of Eastern Finland. 